\title{
Energetic parameters of a population of Chlamys varia (Bivalvia: Pectinidae)
}

\author{
M. S. Shafee ${ }^{1}$ and G. Conan ${ }^{2}$ \\ ${ }^{1}$ Section Halieutique Institut Agronomique et Veterinaire Hassan II, B.P.: 6202, Rabat-Instituts Rabat, Morocco \\ ${ }^{2}$ Centre de Recherche en Biologie Marine, Université de Moncton, Moncton, N. B. E1A 349, Canada
}

\begin{abstract}
Energy relations of a population of black scallop Chlamys varia (L.) in Lanvéoc (Bay of Brest, France) were studied from 1976 to 1978 . The population had a production of $538.52 \mathrm{Kcal}_{100 \mathrm{~m}^{-2}}$ and of $497.10 \mathrm{Kcal} 100 \mathrm{~m}^{-2}$ during the years 1976 to 77 and 1977 to 78 , respectively; it assimilated $5773.21 \mathrm{Kcal} 100 \mathrm{~m}^{-2}$ during the first year and $4561.21 \mathrm{Kcal} 100 \mathrm{~m}^{-2}$ during the second year of this study. Net production efficiency of black scallops (9 to $12 \%$ ) was very low compared to that of other bivalve populations reported so far. Average annual biomass of the population studied was 1252.59 Kcal $100 \mathrm{~m}^{-2}$ and $956.06 \mathrm{Kcal} 100^{-2}$ during the $2 \mathrm{yr}$ period of study. Considerable energy was

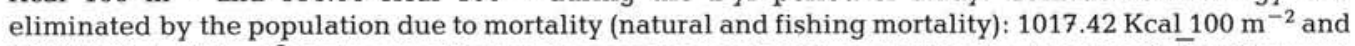
$939.51 \mathrm{Kcal} 100 \mathrm{~m}^{-2}$ during the first and second second year, respectively. Average $\mathrm{P}: \overline{\mathrm{B}}$ ratios were 0.43 and 0.52 during the $2 \mathrm{yr}$.
\end{abstract}

\section{INTRODUCTION}

The black scallop Chlamys varia (L.), a pectinid lamellibranch, is common to Atlantic coasts of France and has been exploited considerably in the Bay of Brest. Although these scallop populations are of economic importance, information concerning the significance of $C$. varia for coastal ecosystems is scant. The present study on a population of $C$. varia in Lanveoc (Bay of Brest) was undertaken to assess its ecological contribution to the ecosystem. Many of the ecological and physiological relations of individual scallops of this population have been described elsewhere (Conan and Shafee, 1978; Shafee, 1979a, b, 1980a, b, 1981, 1982; Shafee and Lucas, 1980, 1982). This study attempts to apply all above-mentioned relations at the population level in order to evaluate the total energy assimilated by the population.

\section{MATERIAL AND METHODS}

Study area. Most observations and field work were conducted in Lanveoc (Fig. 1). Only a limited area of the black scallop bed, covering approximately $360,000 \mathrm{~m}^{2}$ was surveyed since the rest of the area had been prohibited from dredging because of the presence of cables belonging to the French Navy. During the period of this study (1976-1979) scallops were commericially fished every year 3 times a week from October to March.

The population studied was subtidal. Water depth ranged from 6 to $9 \mathrm{~m}$ at lowest spring tides; maximal tidal amplitude was about $6 \mathrm{~m}$. Tidal currents ranged from $0.005 \mathrm{~m} \mathrm{~s}^{-1}$ to $0.63 \mathrm{~m} \mathrm{~s}^{-1}$ at mean spring tides. Bottom sediments were composed mainly of dead calcareous algae (Lithothamnium calcarium) and mud. Chlamys varia was usually associated with other bivalves - such as C. opercularis, Pecten maximus, and Glycymeris glycymeris - and gastropods - such as Buccinum undatum and Ocenebra erinacea. Some echinoderms and hermit crabs were also not uncommon. In addition, there was a rich sessile macrofauna, commensal on C. varia including gastropods (mainly Crepidula fornicata), ascidians, hydrozoans, cirripides and polychaetes. Various brown and red algae grew intensively on the scallop bed during May to December of each year, affecting the dredging of the scallops adversely; they disappeared in the winter.

According to Shafee (1980a), salinity showed little seasonal fluctuation (average value $34.75 \%$ ), but temperature exhibited great seasonal variation with maximum values in July and August $\left(17^{\circ} \mathrm{C}\right)$ and minimum values in February $\left(8^{\circ} \mathrm{C}\right)$. Food availability was measured as chlorophyll $a$ and particulate organic carbon (Shafee, 1980a). Chlorophyll a varied season- 


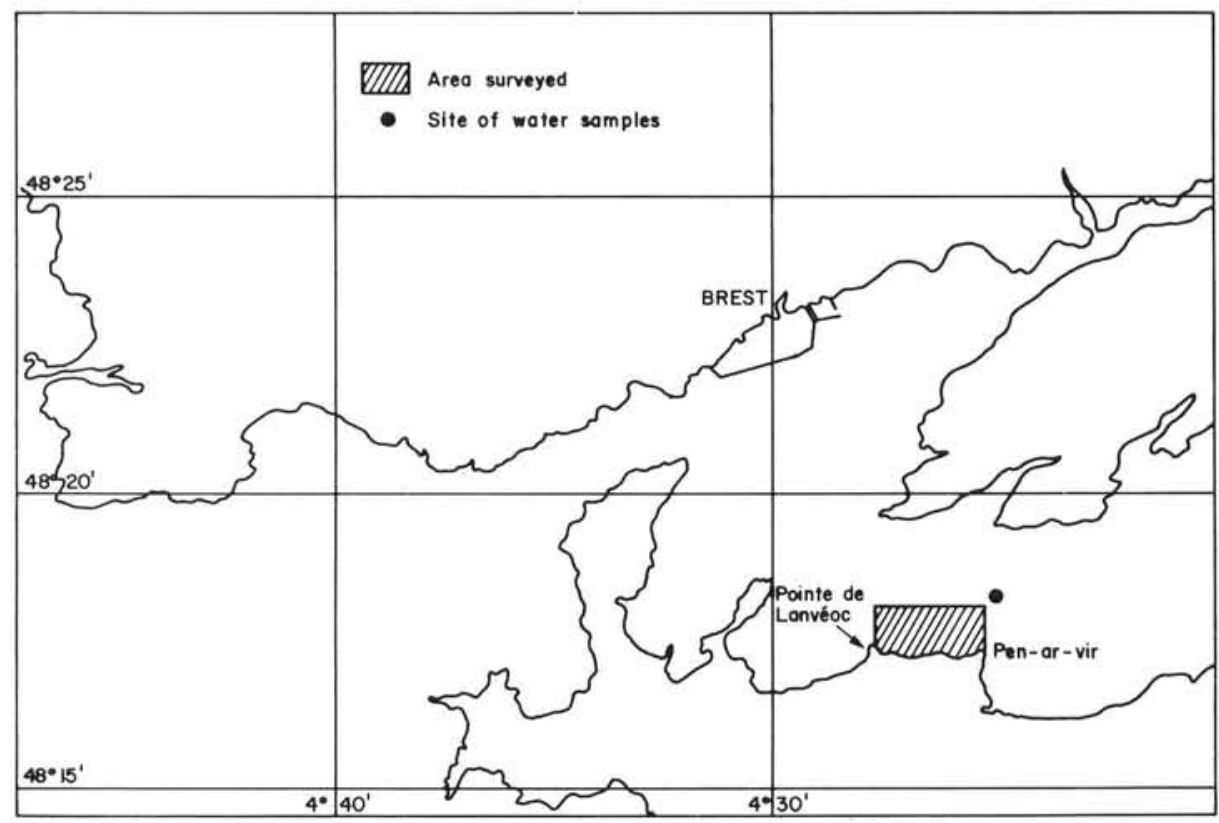

Fig. 1. Location of the population studied

ally with maximal values in April-May (mean monthly values of 3.69 to $4.59 \mathrm{mg} \mathrm{m}^{-3}$ ) and lowest values in winter $\left(0.41\right.$ to $\left.0.06 \mathrm{mg} \mathrm{m}^{-3}\right)$. Smaller peak values of chlorophyll a were noticed in September/October (1.24 to $1.85 \mathrm{mg} \mathrm{m}^{-3}$ ). Particulate organic carbon showed higher values in spring and summer and lowest values in winter.

Sampling techniques. Chlamys varia was sampled at regular monthly intervals from March 1976 to April 1978, using an experimental Standard Pressure Plate dredge (Shafee, 1979a). Three to 5 hauls were made to a distance of 600 or $900 \mathrm{~m}$ for each sampling period. All scallops caught in a dredge haul were separated on board, brought to the laboratory, counted and measured for height (maximal distance between umbo and ventral margin) to the nearest $\mathrm{mm}$.

Statistical treatment: population parameters. Utilizing the data on scallop growth (Conan and Shafee, 1978), the size frequency distribution of each sampling period was divided into component age groups. Younger age groups, which were bimodal, were split into subgroups. The number of scallops in each group was determined by using the technique described by Hasselbald (1966) and later modified by Tomlinson (in Abramson, 1971). Density (D) of each age group $100 \mathrm{~m}^{-2}$ was determined as follows.

$$
\mathrm{D}=\frac{\mathrm{PR} \times 100 \times \mathrm{N}}{\mathrm{DT} \times \mathrm{ED}}
$$

where $\mathrm{PR}=$ proportion of the respective group in a sample; $\mathrm{N}=$ total number of scallops captured by the dredge $;$ DT $=$ distance of the haul ED = efficiency of the dredge divided by 100 , which is equal to 0.076 (Shafee, 1979a).
Mortality and recruitment parameters were assumed to be exponential functions and were calculated as follows:

$$
\mathrm{D}_{\mathrm{t}}=\mathrm{D}_{\mathrm{o}} \cdot \mathrm{e}^{-\mathrm{Mt}}
$$

for mortality estimates and

$$
D_{t}=D_{0} \cdot e^{(R-M) t}
$$

for recruitment estimates, where $D_{t}=$ density of individuals in a particular group at time $t_{;}$Do $=$density of individuals of the respective group at time $=0 ; \mathrm{M}$ and $\mathrm{R}=$ instantaneous coefficients of mortality and recruitment, respectively.

Energy parameter. While calculating the energy parameters, the classical IBP terminology (Petrusewics, 1967; Lucas, 1982) was used:

$$
\mathrm{A}=\mathrm{P}+\mathrm{R}
$$

where $\mathrm{A}=$ total energy assimilated by the population; $\mathrm{P}=$ energy utilized for production of organic matter by the population; $\mathrm{R}=$ energy lost due to metabolic activities (represented by respiration). According to Shafee and Lucas (1982) production in individuals of Chlamys varia occurs in 5 different ways:

$$
\mathrm{P}=\mathrm{P}_{\mathrm{g}}+\mathrm{P}_{\mathrm{s}}+\mathrm{P}_{\text {by }}+\mathrm{P}_{\mathrm{r}}+\mathrm{P}_{\mathrm{n}}
$$

where $\mathrm{P}_{\mathrm{g}}=$ energy incorporated as new body tissues; $\mathrm{P}_{\mathrm{s}}=$ energy spent for shell secretion; $\mathrm{P}_{\mathrm{by}}=$ energy needed for byssus secretion; $\mathrm{P}_{\mathrm{r}}=$ energy liberated as gametes. Production of mucus $\left(P_{n}\right)$ has not been estimated in the present study.

The parameters $\mathrm{P}_{\mathrm{g}}, \mathrm{P}_{\mathrm{s}}$ and $\mathrm{P}_{\text {by }}$ were calculated by 2 different methods: (1) Adding all growth increments of all members of the population as they occur during the period under consideration (Allen, 1951): 


$$
P^{\prime}=\int_{T_{1}}^{T_{2}} N(t) \frac{d \bar{w}(t)}{D T} d t
$$

where $N(t)=$ number of individuals during time $t ; \bar{w}=$ mean weight of an individual during that time; $\mathrm{P}^{\prime}=$ production of the parameters considered $\left(\mathrm{P}_{\mathrm{g}}, \mathrm{P}_{\mathrm{s}}\right.$ or $\left.\mathrm{P}_{\mathrm{by}}\right)$; and $T_{1}$ and $T_{2}=$ beginning and end of the study period, usually 1 yr. (2) Adding the biomass eliminated due to mortality $(\mathrm{E})$ to the residual biomass $(\Delta \mathrm{B})$ after a given time period $(\mathrm{t})$ (Sanders, 1956; Crisp, 1971):

$$
\mathrm{P}^{\prime}=\Delta \mathrm{B}+\mathrm{E}
$$

where $\triangle B=B_{t}-B_{0} ; B_{t}=$ biomass of given parameter after time period $(t) ; B_{0}=$ biomass at sampling period $(\mathrm{t}=0)$.

Growth estimates in this study were based on annual growth rates (Conan and Shafee, 1978). While calculating the amount of shell and byssus secreted by the scallop population, the following relations were used: Ln shell weight $=-8.8944+2.83004 \ln$ height (Shafee, 1981); Ln weight of byssus = $-13.8620+2.0562$ In Height (Shafee and Lucas, 1982). The amount of organic matter present in shell and byssus was estimated by burning them in a muffle furnace.

The biomass eliminated due to total mortality was estimated by integrating mortality and growth parameters in the following equation:

$$
E=\int_{t=0}^{1} D(t) \cdot M \cdot \bar{w}(t) d t
$$

where $\mathrm{t}=$ time in years; $\mathrm{D}(\mathrm{t})=$ density of individuals of a particular age group as a function of time; $\bar{w}(t)=$ weight of an individual in that group as a function of time; $M=$ an instantaneous coefficient of mortality of that particular group. Average biomass during time interval $\mathrm{T}$ was estimated as follows:

$$
\mathrm{B}=\mathrm{E} /(\mathrm{M} . \mathrm{T})
$$

where $\mathrm{E}=$ eliminated energy due to mortality, as calculated above; $\mathrm{M}=$ instantaneous mortality coefficient.

Data on the energy lost due to respiration (R) by individual scallops were obtained from Shafee and Lucas (1982) who, in turn, utilized the following physiological relations (Shafee, 1982):

$$
\begin{aligned}
\mathrm{O}_{2}= & (-89.92+23.37 \mathrm{~T}+1183.76 \mathrm{G}+134.40 \mathrm{~F}) \\
& \mathrm{W}_{\mathrm{bn}}^{0.718} \text { for adults } \\
\mathrm{O}_{2}= & -22.94+309.40 \mathrm{~W}_{\mathrm{bn}}+3.55 \mathrm{~T}+10.25 \mathrm{~F} \\
& \text { for immature scallops }
\end{aligned}
$$

where $\mathrm{T}=$ environmental temperature during the sampling period; $\mathrm{G}=$ gonad index of the scallops during the particular time period; $\mathrm{F}=$ amount of food supply $(F=1$ during spring, summer and autumn; $F=$
0 during winter) $; \mathrm{W}_{\mathrm{bn}}=$ dry body weight of a scallop during that time period. $\mathrm{R}$ was determined for an average weight of an individual of each age group during a sampling period and multiplied by the number of individuals in that group during that sampling period. Annual respiration loss for each age group was calculated by summing the monthly values.

\section{RESULTS}

\section{Analysis of size classes}

Because of several practical problems, discussed by Shafee (1979a), only a few dredge hauls (2 to 5) could be effected for density estimates during each sampling period. Though this limited sampling programme may not be considered adequate for a precise estimate of population parameters, it is possible to arrive at some conclusions which may be considered as a first approximation for future research in this field.

The size-frequency distribution of dredged scallops during each sampling period was split into component age groups. The younger age groups (Group 0) were bimodal due to 2 recruitment periods per year - one in spring, another in autumn (Conan and Shafee; 1978; Shafee and Lucas, 1980). Group 0A, belonging to the spring recruitment, had a mean height of $19 \mathrm{~mm}$; Group $0 \mathrm{~B}$, belonging to the autumn recruitment, had a mean height of $13 \mathrm{~mm}$ during the initial sampling period (March of each year). Settling of spat continued to be slow up to December; number of spat decreased after December. Therefore, recruitment was assumed to occur up to December each year. The older age groups, Groups 1, 2, 3 and 4, had mean heights of 32, 42,45 and $49 \mathrm{~mm}$ during the initial sampling period.

Variation in number of dredged scallops against time is shown in Fig. 2 and 3. Coefficients of equations that best fit these curves are presented in Table 1 which also gives the correlation coefficient of each regression $(\mathrm{r})$, number of samples $(\mathrm{N})$ and calculated density of scallops $100 \mathrm{~m}^{-2}$. Intercepts (a) in Table 1 give the number of dredged scallops in a $100 \mathrm{~m}$ haul during initial sampling; absolute values of slopes (b) represent instantaneous recruitment and mortality rates for Group 0 and later age groups, respectively. Mortality rates for Group 0 scallops could not be estimated from these data; therefore the mortality rate of Group 0 has been assumed to be equal to that of Group 1.

\section{Production due to growth}

Monthly regressions relating height and dry body weight (Shafee, 1981) were pooled and common 

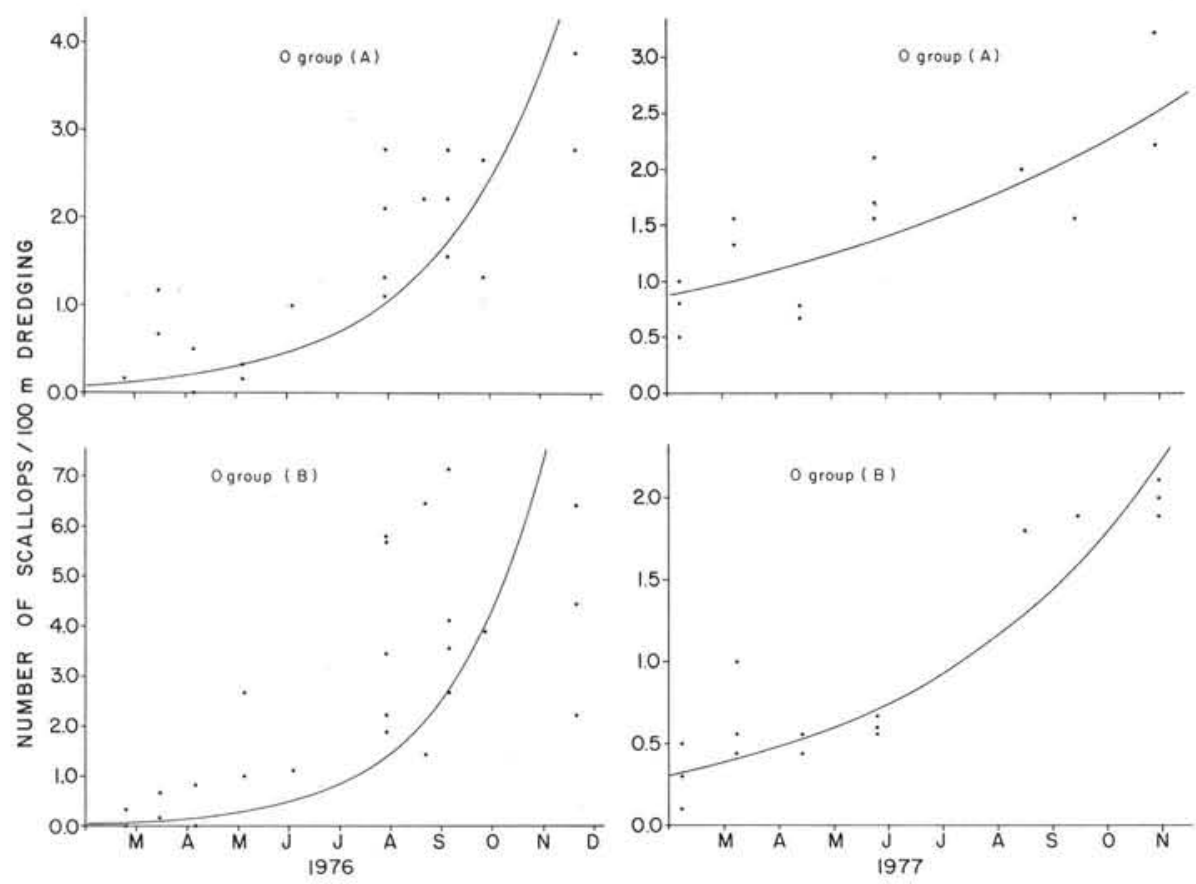

Fig. 2. Chlamys varia. Number (In) of incompletely recruited individuals plotted against time (yr)

Table 1. Chlamys varia. Coefficients of regressions relating ln number of dredged scallops to time (yr)

\begin{tabular}{|c|c|c|c|c|c|c|c|c|c|c|}
\hline \multirow[t]{2}{*}{ Group } & \multicolumn{5}{|c|}{ 1976-1977 } & \multicolumn{5}{|c|}{$1977-1978$} \\
\hline & $\mathrm{a}$ & $\mathrm{b}$ & r & $\mathrm{N}$ & $\begin{array}{l}\text { Calculated } \\
\text { density of } \\
\text { scallops } \\
100 \mathrm{~m}^{-2} \text { at } \mathrm{t}_{\mathrm{o}}\end{array}$ & a & b & r & $\mathrm{N}$ & $\begin{array}{l}\text { Calculated } \\
\text { number of } \\
\text { scallops } \\
100 \mathrm{~m}^{-2} \text { at } \mathrm{t}_{\mathrm{o}}\end{array}$ \\
\hline $0 \mathrm{~A}$ & -2.4386 & 4.0206 & 0.60 & 24 & 1.2 & -0.1328 & 1.0538 & 0.76 & 16 & 11.5 \\
\hline $0 \mathrm{~B}$ & -2.8565 & 5.1896 & 0.60 & 29 & 0.8 & -1.1635 & 1.9521 & 0.86 & 16 & 4.1 \\
\hline 1 & 2.4230 & -1.1920 & 0.81 & 38 & 148.4 & 2.5280 & -2.6600 & 0.92 & 24 & 164.9 \\
\hline 2 & 2.4013 & -1.0505 & 0.65 & 38 & 145.2 & 1.7525 & -1.5563 & 0.78 & 24 & 75.9 \\
\hline 3 & 1.8604 & -0.7103 & 0.54 & 38 & 84.6 & 1.7134 & -0.7002 & 0.65 & 24 & 73.0 \\
\hline 4 & 1.4882 & -1.1016 & 0.55 & 38 & 58.3 & 1.6345 & -0.4338 & 0.55 & 24 & 67.5 \\
\hline
\end{tabular}

Table 2. Chlamys varia. Factors used while calculating the annual production. $\mathrm{W}_{\mathrm{db}}$ : Dry tissue weight $(\mathrm{g})$; $\mathrm{H}$ : height of shell $(\mathrm{mm})$; Cf: calorific value of tissue

\begin{tabular}{|c|c|c|c|c|c|}
\hline Year & $\begin{array}{c}\text { Equation } \\
\text { (Functional regression) }\end{array}$ & $\begin{array}{r}95 \% \\
\text { Elevations }\end{array}$ & $\begin{array}{l}\text { I. } \\
\text { Slopes }\end{array}$ & $\mathrm{N}$ & $\mathrm{r}^{2}$ \\
\hline $1976-1977$ & $\begin{array}{l}\mathrm{L}_{\mathrm{n}} \mathrm{W}_{\mathrm{db}}=-12.56+3.27 \mathrm{l}_{\mathrm{n}} \mathrm{H} \\
\mathrm{Cf}=5.18 \mathrm{Kcal} \mathrm{g}^{-1} \text { (ash free) }\end{array}$ & 0.24 & 0.04 & 1199 & 0.87 \\
\hline $1977-1978$ & $\begin{array}{l}\mathrm{L}_{\mathrm{n}} \mathrm{W}_{\mathrm{db}}=-13.01+3.38 \mathrm{l}_{\mathrm{n}} \mathrm{H} \\
\left.\mathrm{Cf}=5.05 \mathrm{Kcal} \mathrm{g}^{-1} \text { (ash free }\right)\end{array}$ & 0.24 & 0.06 & 972 & 0.92 \\
\hline
\end{tabular}

regressions were developed separately for 1976-77 and 1977-78 (Table 2). By integrating these relations with mortality, density and recruitment estimates obtained in this study, and with growth estimates of Conan and Shafee (1978) and Shafee (1980) production was calculated for the whole population during the 2 years of study, as explained below.
Growth increases of dry body tissue of the survivors in each age group during every monthly sampling period were summed to yield annual production due to growth in each age group (Method I). The resulting value was converted into calorific values using the conversion factors, shown in Table 2. Similarly, increases in weight of shell and byssus were calculated 

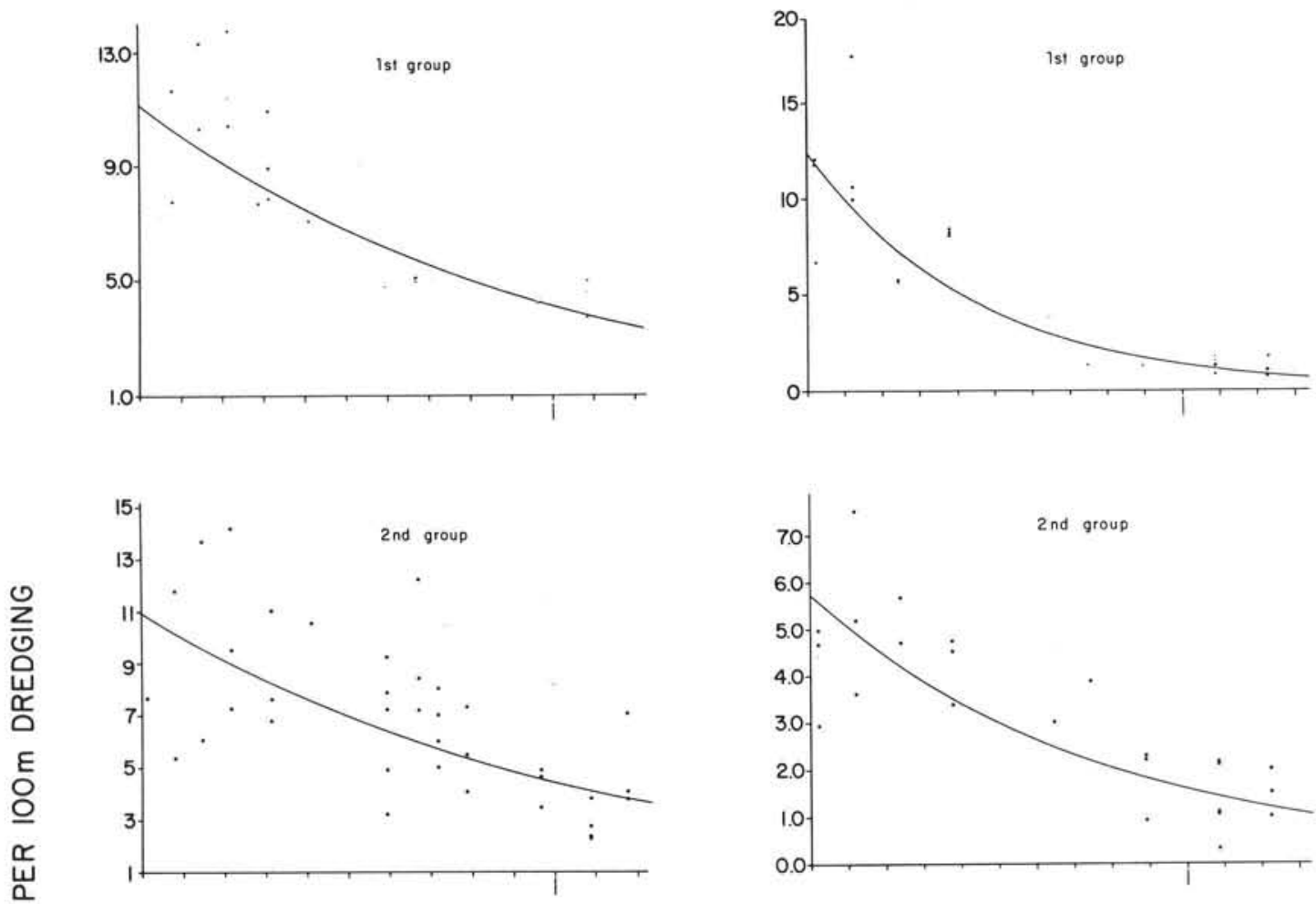

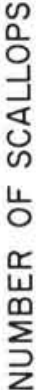
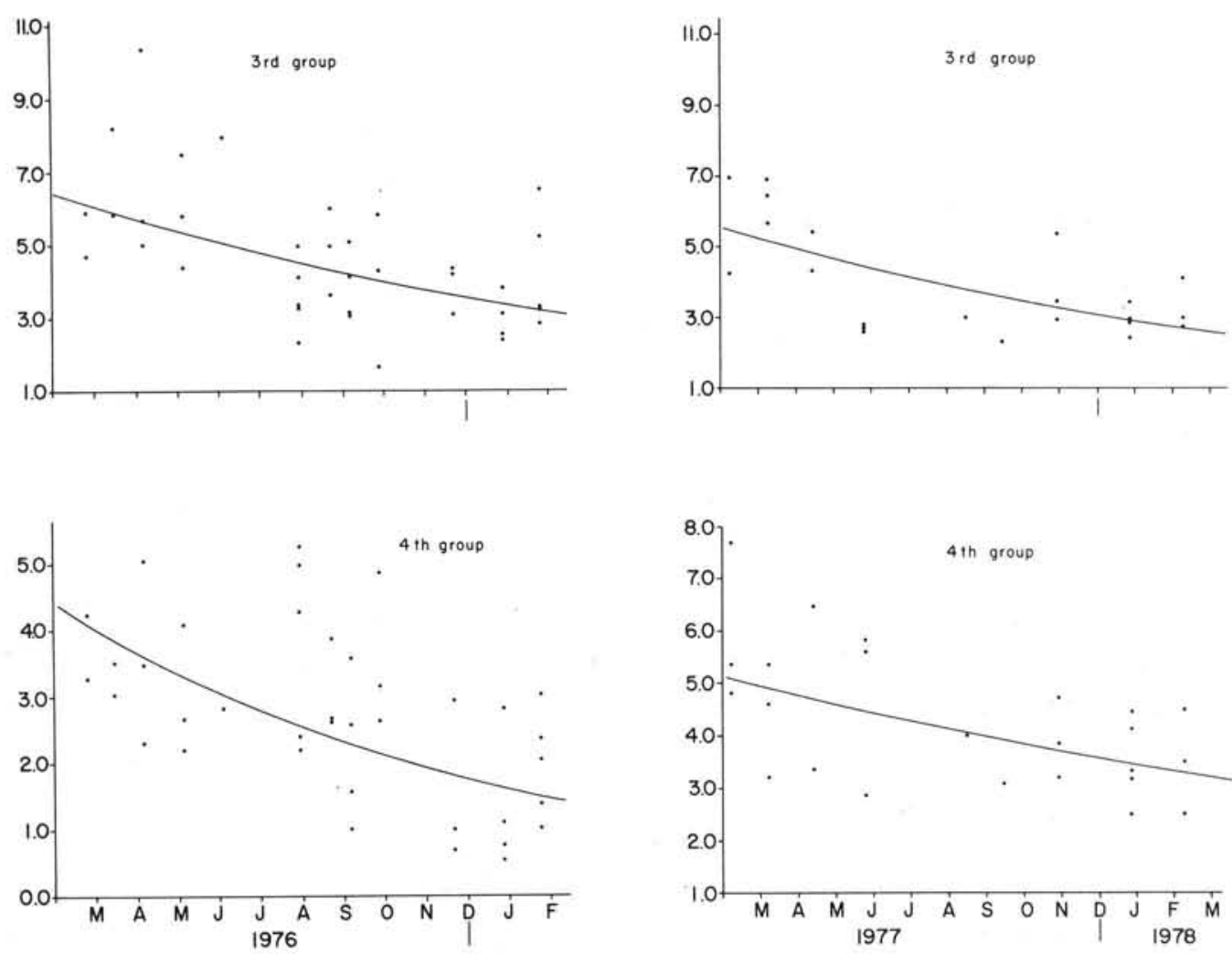

Fig. 3. Chlamys varia. Mortality curves for different age groups 
Table 3. Chlamys varia. Somatic production by the population, estimated by 2 different methods (Values expressed in kcal $\left.100 \mathrm{~m}^{-2}\right) . \mathrm{P}_{\mathrm{g}}$ : Production due to growth; $\mathrm{P}_{\mathrm{s}}$ : production due to secretion of shell; $\mathrm{P}_{\mathrm{by}}$ : production due to secretion of byssus threads; B: residual biomass; E: elimination due to mortality

\begin{tabular}{|c|c|c|c|c|c|c|c|}
\hline \multirow{3}{*}{ Group } & \multicolumn{7}{|c|}{1976} \\
\hline & \multicolumn{4}{|c|}{ Method I: Growth summation } & \multicolumn{3}{|c|}{ Method II: $\Delta \mathrm{B}+\mathrm{E}$} \\
\hline & $\mathrm{P}_{\mathrm{g}}$ & $\mathrm{P}_{\mathrm{s}}$ & $\mathrm{P}_{\mathrm{by}}$ & Total & $\Delta \mathrm{B}$ & E & Production \\
\hline 0 & 56.72 & 17.07 & 0.17 & 73.96 & 70.69 & 36.338 & 107.026 \\
\hline 1 & 127.87 & 31.91 & 0.42 & 160.20 & -60.74 & 213.905 & 153.165 \\
\hline 2 & 103.48 & 25.87 & 0.33 & 129.68 & -190.92 & 314.608 & 123.688 \\
\hline 3 & 57.10 & 11.99 & 0.17 & 69.26 & -142.64 & 210.637 & 67.997 \\
\hline 4 & 17.69 & 3.97 & 0.05 & 21.71 & -221.85 & 241.928 & 20.078 \\
\hline \multirow[t]{2}{*}{ Total } & 362.86 & 90.81 & 1.16 & 454.81 & -585.53 & 1017.416 & 431.888 \\
\hline & \multirow{2}{*}{\multicolumn{4}{|c|}{ Method I: Growth summation }} & & & \\
\hline \multirow[t]{2}{*}{ Group } & & & & & \multicolumn{3}{|c|}{ Method II: $\Delta \mathrm{B}+\mathrm{E}$} \\
\hline & $P_{g}$ & $\mathrm{P}_{\mathrm{s}}$ & $P_{\text {by }}$ & Total & $\Delta \mathrm{B}$ & $\mathrm{E}$ & Production \\
\hline 0 & 45.33 & 12.69 & 0.145 & 58.174 & 43.61 & 62.774 & 106.384 \\
\hline 1 & 124.096 & 31.02 & 0.409 & 155.525 & -170.436 & 318.961 & 148.525 \\
\hline 2 & 45.48 & 11.37 & 0.155 & 57.005 & -151.93 & 214.155 & 62.225 \\
\hline 3 & 46.93 & 9.86 & 0.145 & 56.935 & -134.78 & 184.775 & 50.00 \\
\hline 4 & 20.96 & 4.40 & 0.065 & 25.425 & -131.62 & 158.845 & 27.225 \\
\hline Total & 282.80 & 69.34 & 0.92 & 353.06 & -545.16 & 939.51 & 394.36 \\
\hline
\end{tabular}

for each age group and converted into kilocalories (Shafee and Lucas, 1982). Results are shown in Table 3.

Production $\left(\mathrm{P}_{\mathrm{g}}, \mathrm{P}_{\mathrm{s}}, \mathrm{P}_{\text {by }}\right)$ was also estimated by Method II (explained earlier). Eliminated body tissues, shell and byssus (E) due to total mortality of each age group were estimated for the 2 yr (Table 3 ). Net increase in standing biomass $(\triangle B)$ during a year was estimated separately for each age group, and production due to growth $(\triangle \mathrm{B}+\mathrm{E})$ was calculated by this method (Table 3).

The 2 methods differed from the mean by 2 to $5 \%$ in all age groups during the study period, except for Group 0 individuals where a considerable difference was noticed (see 'Discussion'). However, only the first method (summation of growth increments) has been considered in the present study.

\section{Average annual biomass}

Average annual biomass $(\bar{B})$ of dry tissues, shell and byssus were calculated for each age group for the $2 \mathrm{yr}$ (Table 4). This table also gives the average annual biomass $(\bar{B})$ in Kcal of the whole population for each year. The newly recruited age groups (Group 0) formed only 8 and $5 \%$ respectively of the total population biomass during the first and second year of study.

\section{Assimilated energy}

Utilizing the data on reproduction energy $\left(\mathrm{P}_{\mathrm{r}}\right)$ from Shafee and Lucas (1980) and the calculated values of other production parameters $\left(\mathrm{P}_{\mathrm{g}}, \mathrm{P}_{\mathrm{s}}\right.$ and $\left.\mathrm{P}_{\mathrm{by}}\right)$, production (P) by each age group during the period of study has been calculated and presented in Table 5, which lists also the estimated respiration energy (R) values. The table further gives the amount of energy assimilated by each age group of the population $(P+R)$, and the ratios of $\mathrm{P} / \mathrm{A}, \mathrm{R} / \mathrm{A}, \mathrm{P} / \overline{\mathrm{B}}, \mathrm{R} / \overline{\mathrm{B}}$, and $\mathrm{E} / \overline{\mathrm{B}}$ for each age group.

\section{DISCUSSION}

The population of Chlamys varia in Lanvéoc (Bay of Brest) has a low density level with an average density of 2.3 ind. $\mathrm{m}^{-2}$ during this study period (Shafee, 1979a). Such low density results in a low biomass energy, $1104.33 \mathrm{Kcal} 100 \mathrm{~m}^{-2}$. Approximately 21 and $0.3 \%$ of this standing crop energy can be attributed to shell protein and organic matter in the byssus, respectively. Therefore, a considerable amount of the biomass energy is tied up in an energy sink, the shell, which deteriorates slowly after burial in sand. The organic protein of shells of some bivalves may represent up to $60 \%$ of the total organic material (Price et al., 1972).

The black scallop population in Lanvéoc eliminated a considerable quantity of energy (E) due to total mortality. Instantaneous mortality rates were higher (between 0.43 and 2.66) compared to other species of pectinidae (Broom, 1976; Vahl, 1981). Energy loss due to mortality should be equal to the energy of growth 
$\left(\mathrm{P}_{\mathrm{g}}+\mathrm{P}_{\mathrm{s}}+\mathrm{P}_{\mathrm{by}}\right)$ in a stable population. These estimates in the present study showed that mortality is nearly 2.5 times that of growth energy, indicating that the population biomass is decreasing year by year. Average annual biomass, calculated during the $2 \mathrm{yr}$ period, showed the same trend. The heavy mortality may be due to heavy fishing in that area. After comparing data from $7 \mathrm{yr}$ (1973-1980) on the fishery of black scallops in the Bay of Brest, El Hannach (1980) concluded that the Lanveoc population has been severely overexploited by fishermen during the study period. Shafee and Lucas (1982) further point out that black scallops during most of their life (except for Group 0 individuals) showed a negative index of energy balance resulting in a disadvantage for growth, both at the individual and population level. Probably, such stress would also be a cause for increased mortality rates.

Production, in this study, has been considered as the rate of tissue elaboration by all individuals in a population during a given period of time. The 2 methods employed did not give the same results when calculating the production for Group 0 individuals. During the recruitment period (March to December), variation of mean individual weights between 2 successive sampling periods is not only due to the growth of individuals but is also a function of the settling rate of new spat. Therefore, the growth summation method for Group 0 individuals, in this study, is subject to bias estimates. On the other hand, for removal summation, added to residual biomass method, the mortality rate of Group 0 individuals during the period of recruitment could not be estimated; it has been considered to be equal to that of scallops belonging to the first group. These estimates were integrated along with growth rates for all sampling periods (March to February), in order to calculate the biomass eliminated due to mortality. Possibly, elimination calculated by this method might be overestimated. In that case, for Group 0 individuals, only the results of residual biomass $(\triangle B)$ would be reliable in this study. However, growth summation estimates have been considered in the present study.

One method of comparing the ability of a population to utilize assimilated energy would be to compute the ratios of the different components of the energy budget in relation to assimilation (A). The net production efficiency (NPE) of the black scallop population decreased with increased age, thereby supporting the general statement of Banse (1979) that, within species, NPE decreases with age. On the contrary, the reproductive efficiency and the percentage of non-respired assimilated energy (NRA) channelled into reproduction (reproductive effort) increased with increase in age (Table 7), supporting the general statement for molluscan populations (Browne and Russell-Hunter, 1978).

Table 8 compares the percentage of net production

\begin{tabular}{|c|c|}
\hline $\overrightarrow{0}+\omega N-0$ & $\begin{array}{l}0 \\
\text { : } \\
\text { ㅁํㅁ }\end{array}$ \\
\hline 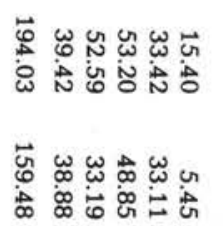 & 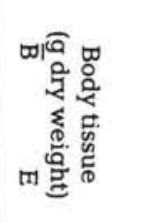 \\
\hline 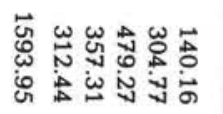 & काख़ी \\
\hline 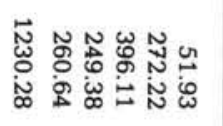 & m鬼 \\
\hline 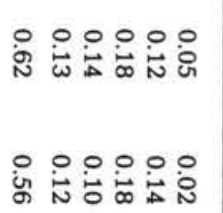 & 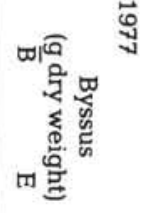 \\
\hline 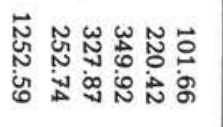 & 띠 조엉 \\
\hline 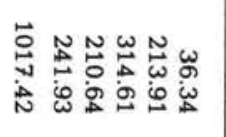 & 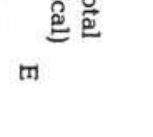 \\
\hline 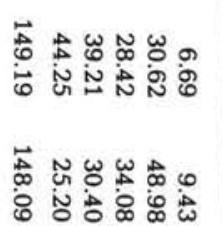 & 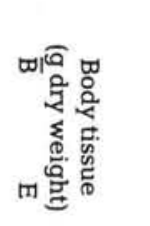 \\
\hline 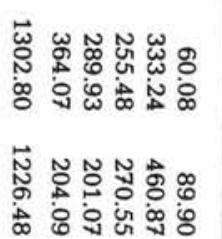 & 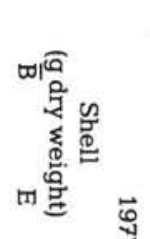 \\
\hline 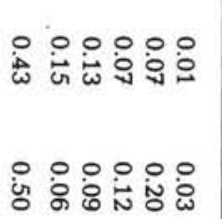 & 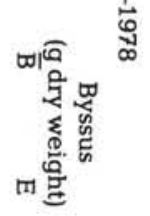 \\
\hline 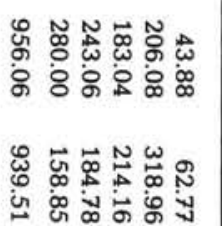 & 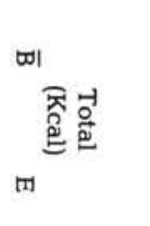 \\
\hline
\end{tabular}


Table 5. Chlamys varia. Different population parameters expressed in energy units (Kcal $\left.100 \mathrm{~m}^{-2}\right)$. $\mathrm{P}_{\mathrm{r}}:$ Reproduction energy (data from Shafee and Lucas, 1980); P: production energy; R: respiration energy; A: assimilation energy; B: average biomass; E: elimination energy due to mortality

\begin{tabular}{|c|c|c|c|c|c|c|c|c|}
\hline \multirow[b]{2}{*}{ Group } & \multicolumn{8}{|c|}{$1976-1977$} \\
\hline & $P_{r}$ & $\mathrm{P}$ & $\mathrm{R}$ & A & $\mathrm{P} / \mathrm{A}$ & $\mathrm{P} / \overline{\mathrm{B}}$ & $\mathrm{R} / \overline{\bar{B}}$ & $\mathrm{E} / \overline{\mathrm{B}}$ \\
\hline 0 & 1.22 & 75.18 & 272.64 & 347.82 & 0.22 & 0.74 & 2.68 & 0.36 \\
\hline 1 & 5.23 & 165.44 & 663.99 & 829.43 & 0.20 & 0.75 & 3.01 & 0.97 \\
\hline 2 & 21.27 & 150.95 & 1588.10 & 1739.05 & 0.08 & 0.43 & 4.53 & 0.90 \\
\hline 3 & 26.82 & 96.08 & 1508.20 & 1604.28 & 0.06 & 0.29 & 4.60 & 0.64 \\
\hline 4 & 29.16 & 50.87 & 1201.76 & 1252.63 & 0.04 & 0.20 & 4.76 & 0.96 \\
\hline \multirow[t]{2}{*}{ Total } & 83.70 & 538.52 & 5234.69 & 5773.21 & 0.09 & 0.43 & 4.18 & 0.81 \\
\hline & \multicolumn{8}{|c|}{$1977-1978$} \\
\hline Group & $P_{r}$ & $\mathrm{P}$ & $\mathrm{R}$ & A & $\mathrm{P} / \mathrm{A}$ & $\mathrm{P} / \overline{\mathrm{B}}$ & $\mathrm{R} / \overline{\mathrm{B}}$ & $\mathrm{E} / \overline{\mathrm{B}}$ \\
\hline 0 & 0.64 & 58.81 & 207.41 & 266.22 & 0.22 & 1.34 & 4.73 & 1.43 \\
\hline 1 & 11.44 & 166.96 & 738.80 & 905.76 & 0.18 & 0.81 & 3.59 & 1.55 \\
\hline 2 & 30.44 & 87.44 & 748.15 & 835.59 & 0.11 & 0.48 & 4.09 & 1.17 \\
\hline 3 & 14.68 & 71.62 & 1069.20 & 1140.8 & 0.06 & 0.30 & 4.40 & 0.76 \\
\hline 4 & 87.30 & 112.73 & 1300.61 & 1413.33 & 0.08 & 0.40 & 4.65 & 0.57 \\
\hline Total & 144.50 & 497.56 & 4064.17 & 4561.27 & 0.12 & 0.52 & 4.77 & 0.98 \\
\hline
\end{tabular}

Table 6. Chlamys varia. Production efficiency of different parameters (production of body tissues $\left[\mathrm{P}_{\mathrm{g}}\right]$, shell $\left[\mathrm{P}_{\mathrm{s}}\right]$, byssus $\left[\mathrm{P}_{\mathrm{by}}\right]$ and gametes $\left[\mathrm{P}_{\mathrm{r}}\right]$ ), in relation to assimilation energy as measured for each group in the population

\begin{tabular}{|c|c|c|c|c|c|c|c|c|}
\hline \multirow[t]{2}{*}{ Group } & \multicolumn{4}{|c|}{$1976-1977$} & \multicolumn{4}{|c|}{$1977-1978$} \\
\hline & $\% \mathrm{P}_{\mathrm{g}}$ & $\% \mathrm{P}_{\mathrm{s}}$ & $\% \mathrm{P}_{\mathrm{by}}$ & $\% P_{r}$ & $\% \mathrm{P}_{\mathrm{g}}$ & $\% \mathrm{P}_{\mathrm{S}}$ & $\% \mathrm{P}_{\mathrm{by}}$ & $\% \mathrm{P}_{\mathrm{r}}$ \\
\hline 0 & 16.31 & 4.91 & 0.05 & 0.35 & 17.03 & 4.77 & 0.06 & 0.24 \\
\hline 1 & 15.42 & 3.85 & 0.05 & 0.63 & 13.70 & 3.43 & 0.05 & 1.26 \\
\hline 2 & 5.95 & 1.49 & 0.02 & 1.22 & 5.44 & 1.36 & 0.02 & 3.64 \\
\hline 3 & 3.56 & 0.75 & 0.01 & 1.75 & 4.11 & 0.86 & 0.01 & 1.29 \\
\hline 4 & 1.41 & 0.32 & 0.01 & 2.33 & 1.48 & 0.31 & 0.01 & 6.18 \\
\hline Mean & 6.29 & 1.57 & 0.02 & 1.45 & 6.20 & 1.52 & 0.02 & 3.17 \\
\hline
\end{tabular}

Table 7. Chlamys varia. Reproduction energy in relation to non-respired assimilated energy, as calculated for each group in the population

\begin{tabular}{|crc|}
\hline Group & $1976-1977$ & $1977-1978$ \\
\hline 0 & 1.62 & 1.09 \\
1 & 3.16 & 6.85 \\
2 & 14.09 & 34.81 \\
3 & 27.91 & 20.50 \\
4 & 57.32 & 77.76 \\
Mean & 15.54 & 29.07 \\
\hline
\end{tabular}

efficiency $(\mathrm{P} / \mathrm{A} \times 100)$ of various bivalves measured at the population or individual level. The net production efficiency of black scallops shows lower values than all the other bivalves studied so far. Faster growth rates of young Chamys varia (Conan and Shafee, 1978; Shafee, 1980 ) result in a higher net production (NPE of groups 0 and 1 were between 18 to 22). On the other hand, larger individuals (Groups 2 to 4 ) approach full final weight more slowly so that they accumulate a major part of the population biomass (ca. $75 \%$ of the biomass), spending a long time at maturity with little somatic weight gain and utilizing practically all the assimilated energy for respiration and reproduction.

In all estimates presented in Table 8, except for Chlamys varia, energy loss due to respiration has been calculated by taking only 2 factors into account: body size and environmental temperature. Laboratory measurements of respiration may lead to underestimates of $R$ because of the intentional use of unfed animals and semi-starvation metabolism. Basal metabolism in larger animals covers only a small part of the total energy expenditure (e. g. Van Hook, 1971; Bailey and Riegert, 1973 Banse, 1978; Humphrys, 1978). According to Widdows (1978), experimental observations relating to the multidimensional character of the natural environment give more precise information on quantitative aspects of respiration in field populations. Vahl (1978) suggested that oxygen consumption of 
Table 8. Percentage of production efficiency in different bivalves

\begin{tabular}{|c|c|c|c|}
\hline Species & $\mathrm{PE} \times 100$ & Habitat & Source \\
\hline Chlamys islandicus & 22.3 & Marine subtidal & Vahl (1981) \\
\hline Chlamys variac & $6-33$ & Marine subtidal & Shafee \& Lucas (1982 \\
\hline Chlamys varia & $9-12$ & Marine subtidal & This study \\
\hline Crassostrea virginica ${ }^{\mathrm{a}, \mathrm{c}}$ & $26-43$ & Intertidal salt marsh & Dame (1971) \\
\hline Crassostrea virginica & 42 & Intertidal salt marsh & Dame (1976) \\
\hline Mercenaria mercenaria & $35-5$ & Intertidal mud flat & Hibbert (1977) \\
\hline Modiolus demissus & 25 & Intertidal salt marsh & Kuenzler (1961) \\
\hline Mytilus californianus ${ }^{b}$ & $8-15$ & Marine intertidal & Fox \& Coe (1943) \\
\hline Mytilus edulis ${ }^{\mathrm{a}, \mathrm{c}}$ & $11-84$ & Marine intertidal & Jørgensen (1952) \\
\hline Ostrea edulis & $25-70$ & Estuarine subtidal & Rodhouse (1978) \\
\hline Ostrea edulis & 29 & Estuarine subtidal & Rodhouse (1979) \\
\hline Patinopecten yessoen & $29-50$ & Marine subtidal & Fuji \& Hashizume (1974) \\
\hline Perna viridis ${ }^{\mathrm{a}, \mathrm{c}}$ & $19-56$ & Estuarine intertidal & Shafee $(1979 b)$ \\
\hline Scrobicularia plana & $21-24$ & Intertidal mud flat & Hughes (1970) \\
\hline Tellina tenuis & $13-29$ & Intertidal sand & Trevallion (1971) \\
\hline \multicolumn{4}{|c|}{${ }^{a}$ Reproduction energy not included } \\
\hline \multicolumn{4}{|c|}{${ }^{\mathrm{b}}$ Data from Trevallion (1971) } \\
\hline \multicolumn{4}{|c|}{${ }^{\circ}$ Production energy of individuals used, not of a population } \\
\hline
\end{tabular}

C. islandica could not be explained by a single factor (temperature) alone, but might be due to a large extent to variations in growth rate, gametogenesis and feeding. Respiration energy loss for the $C$. varia population studied in this paper, has been calculated by integrating various parameters such as body size, temperature, food availability and reproductive activities (Shafee, 1982). Hence, though the respiration estimate was higher than estimates of $\mathrm{R}$ in other beivalves, it may be a more precise value for energy-flow studies.

Engleman (1966) developed a model for predicting yearly production in poikilotherms if respiration $R$ is known. His model was updated by McNeil and Lawton (1970) and afterwards modified by Lévêque (1973):

$$
\log _{10} \mathrm{P}=-0.28+0.83 \log _{10} \mathrm{R}
$$

When Lévêque's (1973) model was used to predict yearly production for the black scallop population, values of $646 \mathrm{Kcal} 100 \mathrm{~m}^{-2}$ and $523 \mathrm{Kcal} 100 \mathrm{~m}^{-2}$ were obtained for the years 1976 to 77 and 1977 to 78 , respectively. These 2 values differed from those of the original by $20 \%$ and $5 \%$, respectively. However, Banse (1979), who compared 20 sets of data on field population of invertebrates, pointed out that it would not be advisable to estimate $\mathrm{P}$ by means of an average relation between $\mathrm{P}$ and $\mathrm{R}$.

Several ecologists assume that there may exist a relation between lifespan and $\mathrm{P}: \overline{\mathrm{B}}$ ratios (e. g. Sanders, 1956; Waters, 1977). When Zaika's (1970) daily specific net production is calculated for black scallops, the resulting value $(0.001)$ corresponds to molluscs having a life span of 7 or 8 yr (Zaika, 1980). If a life span of 8 yr could be assumed for Chlamys varia in the Bay of Brest, Robertson's model (1979) would give a value of 0.6 (using the extreme values of the $95 \%$ confidence limits given in his model) as $\mathrm{P}: \overline{\mathrm{B}}$ ratio for the population studied here. This value is close to the value $(0.5)$ observed during the present study.

Acknowledgements. Professor A. Lucas showed keen interest in the work reported here from its beginning and provided valuable advice. Dr. A. D. Ansell corrected and commented upon the ms.

\section{LITERATURE CITED}

Abramson, J. J. (1971). (Compilation) Computer programmes for fish stock assessments. F. A. O. Fish. Tech. Pap. (101), Pag. var.

Allen, K. R. (1951). The Horokiwi stream. Bull. Mar. Dep. N. Z. Fish. 10: 1-238

Banse, K. (1979). On weight dependence of net growth efficiency and specific respiration rates among field population of invertebrates. Oecologia (Berl.) 38: 11-126

Bailey, C. C., Reigert, P. W. (1973). Energy dynamic of Encoptolophus sordidus coastalis (Scudder) (Orthoptera: Aerididae) in a grassland ecosystem. Can. J. Zool. 5: 91-100

Browne, R. A., Russell-Hunter, W. D. (1978). Reproductive effort in molluscs. Oecologia (Berl.) 37: 23-27

Broom, M. J. (1976). Synopsis of biological data on scallops (Chlamys [Aequipecten] opercularis [Linnaeus] Argopecten irradians [Lamarck] Argopecten gibbus [Linnaeus]). F. A. O. Fish. Synopses 114: 1-44

Conan, G., Shafee, M. S. (1978). Growth and biannual recruitment of black scallops, Chlamys varia (L.) in Lanvéoc area, Bay of Brest. J. exp. mar. Biol. Ecol. 35: 59-71

Crisp, D. J. (1971). Energy flow measurements. In: Holme, N. A., McIntyoe, A. D. (ed.) Methods for the study of marine benthos. IBP Handbook No. 16. Blackwell Scientific Publications, Oxford, 197-279

Dame, R. F. (1971). The ecological energies of growth, respiration and assimilation in the intertidal American oyster, 
Crassostrea virginica. Ph. D. Dissertation, University of South Carolina

Dame, R. F. (1976). Energy flow in an intertidal oyster population. Estuar. coast. mar. Sci. 3: 73-115

El Hannach (1980). Evolution de l'exploitation de pétoncle noir dans le rade de Brest. Rapport de Stage (1979-80) au Centre Océanologique de Bretagne

Engleman, M. D. (1966). Energetics, terrestrial field studies and animal productivity. Adv, ecol. Res. 3: 73-115

Fox, D. L., Coe, W. R. (1943). Biology of the California seamussel (Mytilus californianus). II. Nutrition, metabolism, growth and calcium deposition. J. exp. Zool. 93: 205-249

Fuji, A., Hashizume, M. (1974). Energy budget for a Japanese common scallop, Patinopecten yessoensis (Jay) in Matsu Bay. Bull. Fac. Fish. Hokkaido Univ. 25 (1): 7-19

Hasselbald, V. (1966). Estimation of parameters for a mixture of normal distributions. Technometrics 8: 431-441

Hibbert, C. J. (1977). Energy relations of the bivalve Mercenaria Mercenaria on an intertidal mud-flat. Mar. Biol. 44: 77-84

Hughes, R. N. (1970). An energy budget for a tidal-flat population of the bivalve Scrobicularia plana (da Costa). J. Anim. Ecol. 39: 357-381

Humphreys, W. F. (1978). Ecological energetics of Geolycosa godeffroyi (Aracae: Lycosidae) with an apparaisal of production efficiency in ectothermic animals. J. Anim. Ecol. 47: $637-652$

Jorgensen, C. B. (1952). Efficiency of growth in Mytilus edulis and two gastropod veligers. Nature, Lond. 170: 714

Kuenzler, E. J. (1961). Structure and energy flow of a mussel population in a Georgia salt marsh. Limnol. Oceanogr. 6: 191-204

Leveque, C. (1973). Bilans énergétiques des populations naturelles des mollusques benthiques de Lac Tchad. Cah. Osrtom (Sér. Hydrobiol.) 7: 151-165

Lucas, A. (1982). Remarques sur les rendements de production chez les bivalves marins. Haliotis 12: 47-60

McNeil, S. and Lawton, J. H. (1970). Annual production and respiration. Nature, Lond. 225: 472-474

Petrusewics, K. (1967). Suggested list of more important concept in productivity studies (definition and symbols). In: Petrusewics, K. (ed.) Secondary productivity of terrestrial ecosystems, Vol. I. Polish Scientific Publishers, Warsaw and Cracow, p. 51-82

Price, T. J., Thayer, G. W., La Croix, M. W., Roberts, T. C. (1972). The organic contents of shells, tissues and pallial fluid of some estuarine mollusca and its ecological implications. Ann. Rep. Beaufort, N. C., Estuar. Fish. Lab., 186-190

Robertson, A. I. (1979). The relationship between annual production: biomass ratios and life spans for marine macrobenthos. Oecologia (Berl.) 38: 193-202

Rodhouse, P. G. (1978). Energy transformation by the oyster Ostrea edulis $L$. in a temperate estuary. J. exp. mar. Biol. Ecol. 34: 1-22
Rodhouse, P. G. (1979). A note on the energy budget for oyster population in a temperature estuary. J. exp. mar. Biol. Ecol. 37: 205-212

Sanders, H. L. (1956). Oceanography of Long Island Sound 1952-1954. X. Biology of marine bottom communities. Bull. Bingham oceanogr. Coll. 15: 345-414

Shafee, M. S. (1979a). Underwater observations to estimate the density and spatial distribution of black scallops, Chlamys varia (L.) in Lanvéoc, Bay of Brest. Bull. Off. natn. Pêch. Tunisie 3: 143: 156

Shafee, M. S. (1979b). Ecological energy requirements of the green mussel, Perna viridis (L.) from Ennore estuary Madras. Oceanologica Acta 2: 69-74

Shafee, M. S. (1980a). Application of some growth models to the black scallop, Chlamys varia (L.) from Lanvéoc Bay of Brest. J. exp. mar. Biol. Ecol. 43: 237-250

Shafee, M. S. (1980b). Ecophysiological studies on a temperate bivalve Chlamys varia (L.) from Lanvéoc (Bay of Brest). Thèse de Dr. es. Sci. Nat., Université de Bretagne Occidentale

Shafee, M. S. (1981). Seasonal changes in the biochemical composition and calorific content of the black scallop. Chlamys varia (L.) from Lanvéoc, Bay of Brest. Oceanologica Acta 4: 331-341

Shafee, M. S. (1982). Variations saisonières de la consommation d'oxygene chez le pétoncle noir Chlamys varia (L.) de Lanvéoc (rade de Brest). Oceanologica Acta 5: 189-197

Shafee, M. S., Lucas, A. (1980). Quantitative studies on the reproduction of black scallop, Chlamys varia (L.) from Lanvéoc, Bay of Brest. J. exp. mar. Biol. Ecol. 42: 171-186

Shafee, M. S., Lucas, A. (1982). Variations saisonnier̀res du bilan énergétique chez les individus d'une population de Chlamys varia (L.): Bivalvia, Pectinidae. Oceanologica Acta 5: 331-338

Trevallion, A. (1971). Studies on Tellina tenuis Da Costa. III Aspects of general biology and energy flow. J. exp. mar. Biol. Ecol. 7: 95-122

Van Hook, Jr. R. I (1971). Energy and nutrient dynamics of the spider and orthopteran populations in grassland ecosystem. Ecol. Monogr. 41: 1-26

Vahl, O. (1978). Seasonal changes in the oxygen consumption of the Iceland scallop (Chlamys islandica [O. F. Muller]) from Balsfjord, $70^{\circ}$ N. J. exp. mar. Biol. Ecol. 48: 195-204

Vahl., P. (1981). Energy transformations by the Iceland scallop Chlamys islandica (O. F. Müller), from $70^{\circ} \mathrm{N}$. II. The population energy budget. J. exp. mar. Biol. Ecol. 53: 297-303

Waters, T. F. (1977). Secondary production in inland waters. Adv, ecol. Res. 10: 91-164

Widdows, J. (1978). Combined effects of body size, food concentration and season on the physiology of Mytilus edulis (L) J. mar. biol. Ass. U. K. 52: 109-224

Zaika, V. E. (1970). Rapports entre la productivité des mollusques aquatiques et la durée de leur vie. Cah. Biol. mar. 11: 99-108 